\title{
Value creation through HR shared services: towards a conceptual framework
}

\section{Forthcoming in Personnel Review, Issue 42, Issue 1}

\author{
Jeroen Meijerink \\ University of Twente, School of Management and Governance \\ j.g.meijerink@utwente.nl \\ P.O. Box 217 \\ 7500 AE Enschede, The Netherlands \\ Tanya Bondarouk \\ University of Twente, School of Management and Governance \\ t.bondarouk@utwente.nl \\ P.O. Box 217 \\ 7500 AE Enschede, The Netherlands \\ Jan Kees Looise \\ University of Twente, School of Management and Governance \\ j.c.looise@utwente.nl \\ P.O. Box 217 \\ 7500 AE Enschede, The Netherlands
}

\begin{abstract}
Purpose - The purpose of this paper is to derive a measure for the performance of human resource shared service providers (HR SSPs) and then to develop a theoretical framework that conceptualises their performance.

Design/methodology/approach - This conceptual paper starts from the HR shared services argument and integrates this with the knowledge-based view of the firm and the concept of intellectual capital.

Findings - We recommend measuring HR SSP performance as HR value, referring to the ratio between use value and exchange value, that together reflect both transactional and transformational $\mathrm{HR}$ value. We argue that transactional HR value
\end{abstract}


directly flows from the organisational capital in HR SSPs, whereas human and social capitals enable them to leverage their organisational capital for HR value creation. We argue that the human capital of HR SSPs has a direct effect on transformational HR value creation, while their social and organisational capitals positively moderate this relationship.

Originality/value - The suggested measure paves the way for operationalising and measuring the performance of HR shared services providers. This paper offers testable propositions for the relationships between intellectual capital and the performance of HR shared service providers. These contributions could assist future research to move beyond the descriptive nature that characterises the existing literature.

Key words: human resource shared services, intellectual capital, HR value, implementation of human resource management, HR service delivery.

Paper type: conceptual paper

\section{Introduction}

Today, the provision of human resource (HR) services in organisations is developing through multiple sourcing channels. Recently, organisations have been adopting a relatively new HR sourcing arrangement, known as HR shared services, the focus of this paper. The popularity of HR shared services (often referred to as HR shared service centres) has especially grown due to the beliefs that HR shared service providers (HR SSPs) would integrate centralisation and decentralisation models (Janssen and Joha, 2006). In other words, HR SSPs are seen as simultaneously capturing the benefits of both organisational models, including the strategic alignment 
of HR practices, economies of scale and improved HR service quality (Cooke, 2006; Farndale et al., 2009; Ulrich, 1995).

This research is motivated by two interdependent issues: how to measure and then how to conceptualise HR SSP performance. First, in the literature, one can find several measures for evaluating HR service provider performance, such as HR effectiveness and service quality (Huselid et al., 1997). However, these measures only partially take into account the proclaimed benefits and performance of HR SSPs. The concept of HR service quality, for example, only measures the realisation of benefits linked to decentralisation models, and ignores centralisation benefits such as economies of scale and efficiency. Without appropriate measures, empirically investigating HR SSP performance remains a challenge (Farndale et al., 2009).

Second, despite the novelty of the concept, research has already answered questions such as why organisations implement HR shared services, which HR services are shared and how HR SSPs are structured (Farndale et al., 2009; Janssen and Joha, 2006; Redman et al., 2007). Further, it is generally recognised that consolidated knowledge resources are vital if HR SSPs are to perform satisfactorily. Ulrich (1995), for example, foresees it that HR shared service employees will 'build consistency through sharing a common base of knowledge' (p. 15), and Farndale et al. (2009) have observed that managers perceive having staff with the appropriate competencies and skills as the key factor for shared services success. However, notwithstanding these contributions, the existing knowledge on HR shared services remains descriptive and does not explain in which ways and to what extent HR shared service providers realise the benefits of both centralisation and decentralisation models (Farndale et al., 2009; Strikwerda, 2004). 
Challenging questions regarding HR shared services models therefore remain, such as in what way do the combined knowledge resources contribute to a highquality and low-cost HR delivery by HR SSPs, and under what conditions can HR SSPs utilise consolidated knowledge resources to deliver HR shared services benefits? Given this situation, the purpose of this paper is: (1) to develop a conceptual framework that conceptualises HR SSP performance and benefits through its utilisation of knowledge resources and (2) to propose a measure for HR SSP performance. To develop our conceptual framework, we start from the knowledgebased view of the firm and combine this with the intellectual capital concept as, together, they enable one to explain how the knowledge resources of HR SSPs contribute to their performance (Grant, 1996; Spender, 1996).

In so doing, this paper makes two contributions. First, it offers testable propositions on how concentrated knowledge resources affect the success of HR shared services, and thus it creates a basis for empirical studies. Secondly, in practical terms, it provides guidelines for HR shared service managers on how to effectively manage HR SSPs.

In the remainder of this article, we first describe the characteristics of HR shared services, and define their benefits and performance in terms of $H R$ value. We then examine the characteristics of intellectual capital, its sub-dimensions, and how these relate to one another. Finally, we build propositions by focusing on the interdependencies among the intellectual capital sub-dimensions and their relationships with HR value. We argue that different interrelationships are required depending on the type of value that one wishes to create for end-users (i.e. employees and line managers) and clients (i.e. the business units). 


\section{HR shared services: from structure to values}

\subsection{The centralisation-decentralisation debate}

Implementing HR shared services is seen as a response to the question of whether firms should centralise or decentralise their HR function (or parts thereof) to increase economies of scale or improve local responsiveness (Farndale et al., 2009; Quinn et al., 2000; Strikwerda, 2004). Centralisation refers to the extensive, corporate-level control of activities and resources, with corporate-level staff functions being established to ensure economies of scale at the expense of meeting business unit priorities (Janssen and Joha, 2006). Decentralisation, on the other hand, secures business unit responsiveness by granting full business-unit control over HR activities, but makes HR service delivery costly due to resource duplication (Janssen and Joha, 2006; Reilly, 2000).

When establishing shared services, organisations centralise activities and resources in a (semi-) autonomous business unit: the shared service provider. Research shows that HR activities commonly performed by HR SSPs include personnel administration, training and staffing tasks, which are delivered as HR services through the use of concentrated resources such as information technologies and HR knowledge and skills (Bondarouk et al., 2010). Although activities and resources are centrally bundled within an HR SSP, some have warned against confusing shared services with centralisation. Redman et al. (2007), for example, emphasise that, despite the consolidation of resources, 'power and control rest with the customer' (p. 1487). Ulrich (1995) goes further by suggesting that shared services are the opposite of centralisation. Whereas, in centralisation models, decision-making and control are in the hands of a corporate-level entity, such as the board of directors; with shared services, the clients and end-users are, at least in theory, in control. This 
involves the business units choosing 'the type, level and quality of services they want from the centre, at the price they are willing to pay' (Quinn et al. 2000, p.13, italics added). Reilly and Williams (2003) describe an HR SSP where business units are involved in the design of new HR services to the extent that they determine and develop these HR services together with the HR SSP. Ulrich (1995) puts it that, with shared services, the 'user is the chooser' (p. 14). In other words, the business units have control over centralised resources and activities. In line with these features, we define HR shared services as a hybrid organisational model for centrally bundling resources in an HR shared service provider that performs HR activities to be controlled by its end-users and business units. As such, the key characteristics of HR shared services are the centralisation of resources combined with the decentralisation of control to business units. In this way, HR SSPs differ from the traditional, corporate HR department because, despite the fact that both centralise resources and activities, only the former simultaneously decentralises control to the business unit.

\subsection{The benefits of HR shared services as HR value}

Through combining centralisation and decentralisation models, organisations anticipate being able to capture the benefits of both, while minimising their drawbacks (Janssen and Joha, 2006). Centralisation models offer economies of scale and scope by eliminating the duplication of activities and resources, but they also lead to long response times and tend to lose focus on the needs of the business units (Janssen and Joha, 2006). With decentralisation models, responses to change are faster and business units needs are better supported, but cost levels are high as resources are duplicated (Strikwerda, 2004). Both organisational models therefore are double-edged 
swords: both have benefits and liabilities, with the drawbacks of one model mirroring the benefits of the other (see Table I).

\begin{tabular}{|l|l|l|l|}
\hline \multicolumn{2}{|c|}{ Centralisation models } & \multicolumn{2}{c|}{ Decentralisation models } \\
\hline \multicolumn{1}{|c|}{ Liabilities } & \multicolumn{1}{c|}{ Benefits } & \multicolumn{1}{c|}{ Benefits } & \multicolumn{1}{c|}{ Liabilities } \\
\hline $\begin{array}{l}\text { Limited local } \\
\text { responsiveness }\end{array}$ & $\begin{array}{l}\text { Economies of scale } \\
\text { and scope }\end{array}$ & $\begin{array}{l}\text { Local } \\
\text { responsiveness }\end{array}$ & Higher costs \\
\hline Inflexibilities & $\begin{array}{l}\text { Consistent HR } \\
\text { service delivery }\end{array}$ & Flexibility & $\begin{array}{l}\text { Inconsistent } \\
\text { standards }\end{array}$ \\
\hline $\begin{array}{l}\text { Slow decision- } \\
\text { making }\end{array}$ & Efficiency & $\begin{array}{l}\text { Speedy decision- } \\
\text { making }\end{array}$ & $\begin{array}{l}\text { Duplication of } \\
\text { resources }\end{array}$ \\
\hline $\begin{array}{l}\text { Little consideration } \\
\text { for local priorities }\end{array}$ & Strategic alignment & $\begin{array}{l}\text { Extensive control } \\
\text { at the business unit } \\
\text { level }\end{array}$ & $\begin{array}{l}\text { Inconsistent HR } \\
\text { service delivery }\end{array}$ \\
\hline $\begin{array}{l}\text { Large distance to } \\
\text { business units }\end{array}$ & $\begin{array}{l}\text { Best practice } \\
\text { sharing }\end{array}$ & $\begin{array}{l}\text { Responsive to end- } \\
\text { user needs }\end{array}$ & $\begin{array}{l}\text { Little sharing of } \\
\text { best practices }\end{array}$ \\
\hline
\end{tabular}

Table I: Benefits and liabilities of centralisation and decentralisation models for HR service delivery

Research has shown that firms establish HR SSPs to achieve cost reductions by centrally bundling resources while, at the same time, responding to business unit and end-user needs through delegating control over HR service delivery to the business units (Farndale et al., 2009; Redman et al., 2007). In balancing the liabilities and benefits of centralisation and decentralisation, organisations expect to reap concrete benefits such as quick decision-making, the consistent implementation of HR policies and processes, the creation of synergies, increased productivity, better management information, greater transparency of cost of services, reduced administrative HR workloads and an increased strategic contribution from HR professionals (Cooke, 2006; Janssen and Joha, 2006; Reilly, 2000). According to Farndale et al. (2009), implementing HR shared services is therefore likely to have an impact on two out of the four logics defined by Paauwe (2004): the professional and the delivery logics. According to Paauwe (2004), the former refers to the degree of customer orientation in the HR function and the quality of its services (i.e. reflecting the realisation of 
decentralisation benefits), and the latter concerns the cost-effectiveness of HR service delivery (i.e. reflecting the realisation of centralisation benefits).

HR SSPs see themselves as being controlled by business units and end-users (Strikwerda, 2004), meaning that the clients and end-users are likely to capture the benefits that their HR SSP realises. We therefore limit our considerations to the benefits for the clients (i.e. the business units) and end-users (i.e. employees, line managers and HR professionals), and argue that it is important to consider how these stakeholders evaluate the performance of HR SSPs. Empirical studies have accumulated rich knowledge on the evaluation of HR service providers, including measures for aspects such as satisfaction with HR services, HR service quality, perceived HR function performance and HR effectiveness (Alleyne et al., 2007; Boselie and Paauwe, 2005; Huselid et al., 1997). With some overlap, these constructs measure the extent to which HR service providers meet the needs or expectations of HR stakeholders, such as in terms of service delivery timeliness and speed (Tsui, 1987), responsiveness (Mitsuhashi et al., 2000) and customer focus and helpfulness (Gibb, 2001). However, by focusing on the degree of business unit and end-user responsiveness, these measures predominantly reflect the benefits of decentralisation models, whilst largely ignoring the centralisation benefits of HR shared services such as cost reductions and a reduction in resource duplication (Cooke, 2006). Therefore, we see the need for an integrative performance measure that measures the extent to which both centralisation and decentralisation benefits are realised by an HR SSP, as seen by its clients and end-users.

A measure that captures both benefits of HR shared services is $H R$ value as this relates the fulfilment of business-unit needs with the costs involved in consuming HR services. In service management, value has been thought of as the client's 'overall 
assessment of the utility of a service based on the perceptions of what is received and what is given' (Zeithamel, 1988: 15, italics are ours). To operationalise value, the definition of value has been operationalised and captured in the ratio of use value (i.e. what is received) to exchange value (i.e. what is given). In the literature, use value has been defined as 'the quality of a (...) service as perceived by users in relation to their needs' (Bowman and Abrosini, 2000: 2). Use value reflects the extent to which a service meets the needs of those who use it (Priem, 2007) and so reflects the decentralisation benefits of HR shared services. In an HR shared service environment, use value therefore refers to the extent to which the HR services of the HR SSP fulfil the needs of their clients and end-users (Bowman and Ambrosini, 2000). Exchange value, on the other hand, has been defined as the 'amount paid by the user to the seller for the use value of the focal (...) service' (Lepak et al., 2007: 182). Put differently, it reflects the costs that users make in consuming a service (Lapierre et al., 1999; Priem, 2007; Zeithaml, 1988), and so exchange value echoes with centralisation benefits such as economies of scale and cost reduction. Costs can be monetary, such as fees or prices paid for HR services, and also non-monetary, such as the effort and time that clients and end-users need to devote to receive the HR services. Exchange value in an HR shared services context therefore refers to the amount of money, effort and time clients and end-users spend to obtain HR services from the HR SSP.

HR value reflects the ratio between use value and exchange value, meaning that HR value increases when the needs of clients and end-users are better met, or when the costs for obtaining HR services incurred by clients and end-users reduce. However, research has found that high value is often equated with a low exchange value or simply with a high exchange value. As an example, Lapierre et al. (1999) found that exchange value has a stronger impact on value creation than has use value. 
However, others have found that value creation is more strongly, or only, influenced by use value (Cronin et al., 2000; Grewal et al., 1998). Increasing use value and reducing exchange value are therefore not necessarily equally effective in increasing HR value, as further discussed below.

\subsection{Transactional and transformational HR value}

Within an HR shared services model, two distinct types of HR services are offered: transactional and transformational (Farndale et al., 2009; Redman et al., 2007; Ulrich, 1995). Empirical research has shown that transactional shared HR services offered include absence registration, record-keeping and payroll administration; whereas transformational shared HR services include training plus development and/or staffing services (Bondarouk et al., 2010). Research into HR service evaluation reveals that the assessments by clients and end-users differ for transactional and transformational HR services (Buyens and De Vos, 2001). Transactional HR services are valued for being cheap and errorless, whereas transformational HR services are for implementing training and staffing policies as intended (Buyens and De Vos, 2001; Lepak et al., 2005). This implies that HR SSPs can create two types of HR value, namely: transactional HR value and transformational HR value, both of which having a use value and an exchange value component (see Table II).

\begin{tabular}{|c|c|c|c|}
\hline \multicolumn{2}{|c|}{ Transactional HR value } & \multicolumn{2}{|c|}{ Transformational HR value } \\
\hline Use value: & Exchange value: & Use value: & Exchange value: \\
\hline $\begin{array}{c}\text { The extent to } \\
\text { which HR } \\
\text { services are } \\
\text { delivered in a } \\
\text { timely, accurate } \\
\text { and standardised, } \\
\text { or consistent, } \\
\text { manner }\end{array}$ & $\begin{array}{l}\text { The amount of } \\
\text { money, effort and } \\
\text { time clients and } \\
\text { end-users spend } \\
\text { to receive } \\
\text { transactional HR } \\
\text { services }\end{array}$ & $\begin{array}{l}\text { The extent to which } \\
\text { HR services are } \\
\text { customised and support } \\
\text { increasing the rarity } \\
\text { and inimitability of the } \\
\text { human capital of the } \\
\text { business units they } \\
\text { serve }\end{array}$ & $\begin{array}{l}\text { The amount of } \\
\text { money, effort and } \\
\text { time that clients and } \\
\text { end-users spend to } \\
\text { receive } \\
\text { transformational } \\
\text { HR services }\end{array}$ \\
\hline
\end{tabular}




\begin{tabular}{|c|c|c|c|}
\hline $\begin{array}{c}\text { Secondary } \\
\text { component }\end{array}$ & $\begin{array}{c}\text { Principal } \\
\text { component }\end{array}$ & $\begin{array}{c}\text { Principal } \\
\text { Component }\end{array}$ & $\begin{array}{l}\text { Secondary } \\
\text { component }\end{array}$ \\
\hline
\end{tabular}

Table II: Value of HR shared services: transactional vs. transformational HR value

\subsubsection{Transactional HR value}

The delivery of transactional HR services creates use value through meeting the administrative needs of end-users and business units. Research shows that these needs include timely and consistent HR service delivery, faultless HR administration and a standardised provision of transactional HR services (Buyens and De Vos, 2001; Lepak et al., 2005; Ulrich, 1995). As such, use value in a transactional HR environment refers to the extent to which HR services are delivered in a timely, accurate and standardised, or consistent, manner. For transactional HR services, exchange value amounts to the amount of money, effort and time clients and endusers spend to receive transactional HR services.

Transactional HR services are viewed as a hygiene factor, that is they do not increase end-user satisfaction once their quality exceeds a certain threshold, but may lower satisfaction if delivered poorly (Boselie and Paauwe, 2005). In other words, transactional HR services might not create value beyond a certain level even if their use value increases. However, transactional HR services, because these services are usually offered in large volumes, can lead clients and end-users to anticipate economies of scale (Farndale et al., 2009; Lepak et al., 2005). Cooke (2006) reports low levels of satisfaction with transactional HR shared services among line managers because they felt they were wasting their time and effort using the offered HR services. These end-user evaluations were negative due to the low levels of exchange value that resulted from a sub-optimal allocation of resources (Cooke, 2006). For clients, a low-cost delivery of transactional HR services seems to be most important, which echoes with existing research showing that the primary motive for establishing 
transactional HR SSPs is indeed to reduce costs (Bondarouk et al., 2010; Farndale and Paauwe, 2008; Redman et al., 2007). Our anticipation is therefore that, within a transactional HR shared service environment, the emphasis will be on exchange value, rather than on use value, as a way of creating transactional HR value: that is, exchange value is the principal component of transactional HR value for clients and end-users.

\subsubsection{Transformational HR value}

Transformational HR SSPs are responsible for putting staffing, training and development policies into practice with the goal of transforming the human resources of the organisation (Redman et al., 2007; Ulrich, 1995). Research shows that transformational HR services differ by employment mode. For example, within a jobbased employment mode, employees will receive training that emphasises their job experiences, whereas employees in a contractual work arrangement receive training that focuses on compliance with rules and procedures (Lepak and Snell, 2002). These variations in employment mode require transformational HR SSPs to customise their HR services and tailor them to the different business units or groups of end-users. Further, transformational HR services such as staffing and training can help in acquiring or developing the human capital (i.e. knowledge, skills and experiences of end-users) of the business units served by the HR SSP (Lepak et al., 2006). In particular, HR SSPs can support their clients in developing a competitive workforce with rare and inimitable human capital. This follows from the idea that putting HR policies into practice is a source of competitive advantage in itself, and that this will be supported by an HR SSP when it manages to better implement staffing and training policies than the HR SSPs of competitor firms (Barney, 2001; Becker and Huselid, 
2006). Transformational HR SSPs therefore create use value to the extent that they offer customised HR support for clients and end-users, and support increasing the rarity and inimitability of the human capital of the business units they serve.

Given the arguments above, we assume that clients and end-users will value transformational HR services for providing the firm with a competitive workforce, rather than only for being cost-efficient. While HR SSPs may reduce the price of such HR services, this, on its own, is unlikely to increase the value for end-users. For example, end-users in a study by Buyens and De Vos (2001) reported that transformational HR service providers primarily create value by implementing HR strategies as they were intended, and offering high-quality transformational HR services, rather than simply by offering cheap HR services. Further, end-users and clients will only value a cost-efficient delivery of transformational HR services when those services meet their transformational needs (Buyens and De Vos, 2001). On this basis, we argue that use value is the principal component of transformational HR value for clients and end-users.

\section{Intellectual capital as an antecedent of $H R$ value}

The knowledge-based view argues that value follows from the knowledge resources available within an organisation (Grant, 1996; Spender, 1996). Grant (1996: 112) argues that 'fundamental to a knowledge-based theory of the firm is the assumption that the primary input in production and primary source of value is knowledge'. In general, a resource is considered valuable to the extent that it enables a firm to better satisfy, or at lower costs, the needs of its clients than its competitors (Barney, 1986; Bowman and Ambrosini, 2000). Most organisations establish HR SSPs that then offer services to captive clients and end-users (Bondarouk et al., 2010) and, as such, HR 
SSPs do not have to compete with others. In an HR shared service environment, knowledge resources are therefore valuable to the extent that they enable an HR SSP to satisfy the needs of clients and end-users and/or provide HR services at low costs. HR SSPs bundle a wide range of knowledge resources: the expertise of HR professionals (Cooke, 2006), information obtained from client relationships (Ulrich, 1995) and knowledge embedded in processes, information technologies and routines (Farndale et al., 2009; Ulrich, 1995). Such knowledge resources are considered valuable for HR SSPs. Empirical research into the HR competencies (i.e. knowledge, skills and experiences) of HR staff suggests that their knowledge and skills impact on HR value for clients and end-users. For example, in a study into 441 organisations, the competencies of the HR SSP staff was found to account for approximately $20 \%$ of the variance in the effectiveness, as perceived by clients, of HR SSP staff (Ulrich et al., 2008).

To conceptualise the entire pool of knowledge resources that are centralised within an HR SSP, we build on the intellectual capital concept, which has been defined as 'the sum of all knowledge an organization is able to leverage in the process of conducting business to create value' (Youndt et al., 2004: 337, italics are ours). Two notions are important with respect to intellectual capital. First, value does not come from the possession of knowledge resources: knowledge only creates value when it is used (Bukh et al., 2001; Penrose, 1952). As such, the utilisation of knowledge is central to the intellectual capital concept, which stresses that knowledge has to be utilised before it can be considered as intellectual capital (Youndt et al., 2004). Second, knowledge resources are seldom valuable in isolation: several scholars have argued that value creation should be considered as a product of the coexistence of different types of knowledge resources such as employee knowledge, routines and 
processes, rather than focussing on utilising single, decoupled knowledge resources (Ruta, 2009; Youndt et al., 2004). Given these considerations, we define intellectual capital as the combinations of knowledge resources that an HR SSP utilises to create $H R$ value for clients and end-users. Using the concept of intellectual capital is valuable in conceptualising HR value creation by HR SSPs because it mirrors the centralisation concept that characterises HR shared services: knowledge resources have to be centralised, bundled and combined in an HR SSP in order to reap the benefits for clients and end-users. In this way, our contribution differs from research into strategic HRM that has studied the contribution of human resource management to the development of intellectual capital within business units or an entire organisation (Yang and Lin, 2009; Youndt and Snell, 2004). Rather, we focus on how HR SSPs may utilise the knowledge resources they consolidate to create HR value for their end-users and clients. In other words, we consider the intellectual capital that resides within HR SSPs and treat this as an antecedent of HR value.

The intellectual capital concept holds that the knowledge resources within an organisation reside on three levels: the individual, the network and the organisational levels (Bontis, 1998; Youndt et al., 2004). To operationalise intellectual capital, we follow others who subdivide intellectual capital into three sub-dimensions: human capital, social capital and organisational capital (Reed et al., 2006; Ruta, 2009; Youndt et al., 2004). On the individual level, the human capital of an HR SSP reflects the knowledge, skills and abilities of employees that are valuable to the organisation (Liao et al., 2009; Snell and Dean, 1992). Originally, human capital scholars studied the extent to which the firm or employees themselves incur the costs for the investments in human capital, which depended on the nature of the skills (generic versus firm-specific) and associated future returns on investments (Lepak and Snell, 
2002; Snell and Dean, 1992). Although various entities may invest in human capital, central to this debate is the development of human capital through education or training that increase employees' knowledge and skills. Hence, these investments will be reflected in the degree to which human capital is developed. Therefore, we define human capital as the level of knowledge, skills and abilities of HR SSP staff. To conceptualise the human capital in HR SSPs, we depart from the HR competencies concept as HR competencies reflect the knowledge, skills and abilities of HR professionals (Boselie and Paauwe, 2005; Han et al., 2006). Research into HR competencies has shown that the human capital of HR SSPs may include knowledge on functional HR practices (such as training, staffing or record keeping), the firm's value proposition plus workforce characteristics or skills to utilise information technology for HR service delivery (Boselie and Paauwe, 2005; Han et al., 2006; Yeung et al., 1996). Conceptual arguments and empirical results suggest that the knowledge, skills and experiences of HR SSP staff run along two dimensions. For instance, Yeung et al. (1996) argue that HR professionals in HR SSPs should have the knowledge and abilities to deliver best-in-class HR practice plus the ability to apply HR information technologies. This argument has been supported by factor analysis showing that the HR competencies within HR SSPs reflect the ability to execute HR practices and the ability to utilise HR technologies (Ulrich et al., 2008). Taken together, these works suggest that employees of HR SSPs have, on the one hand, content-related human capital linked to HR practices and how they should be implemented and, on the other, human capital for utilising support infrastructures such as HR information technologies. In this paper, the human capital of HR SSP staff is therefore operationalised as HR functional human capital (i.e. the level of knowledge of HR SSP staff on HR practices and their ability to execute them) and HR 
infrastructural human capital (i.e. the level of ability of HR SSP staff to use infrastructures such as HR information technologies, databases and HR processes).

On the network level, social capital amounts to the knowledge that is mobilised through social relationships (Nahapiet and Ghoshal, 1998; Youndt et al., 2004), with knowledge mobilisation having been shown to be dependent on relationships (Coleman, 1988; Tsai and Ghoshal, 1998). It represents the knowledge exchanged among HR SSP staff within the HR SSP. Given that employees differ in the intensity with which they exchange knowledge (Haas and Hansen, 2007), we define social capital as the extent to which knowledge is exchanged among employees through the social interrelations within the HR SSP.

On the organisational level, the organisational capital of an HR SSP is a reflection of the organisational knowledge which is codified, embedded or stored in knowledge containers such as databases, routines, information technologies, HR processes and manuals (Bukh et al., 2001; Yang and Lin, 2009; Youndt et al., 2004). Given its embedded and codified nature, organisational capital may be considered as the knowledge that stays behind when employees 'leave for the night' (Bontis, 1998; Youndt et al., 2004). HR SSPs rely on organisational capital in the form of HR information technologies, such as HR portals and online self-services for HR service delivery, and standardised HR processes (Farndale et al., 2009; Ulrich, 1995). Organisations are not able to codify all the available knowledge (Haas and Hansen, 2007), and HR SSPs can differ in the degree to which they store knowledge in accessible knowledge containers. As such, organisational capital refers to the extent to which an HR SSP has embedded or codified knowledge in databases, routines, information technologies, HR processes and manuals. To operationalise organisational capital, existing studies point to considering how organisational capital 
may be designed and, hence, how employees use codified knowledge. On the one hand, processes, rules and structures can be designed such that employees have to strictly comply with procedures or processes in a consistent, rule-following manner (Daft and Weick, 1984; March and Simon, 1958; Ostroff and Schmitt, 1993). On the other hand, organisational capital may be designed and used more loosely as if it were guidelines which offer autonomy but within boundary conditions for possible action (Eisenhardt and Sull, 2001; Feldman and Pentland, 2003; Pentland and Reuter, 1994). We therefore follow Kang and Snell (2009) in conceptualising organisational capital as either mechanistic (the extent to which an HR SSP has embedded or codified knowledge as rules that have to be followed strictly and consistently) or organic (the extent to which an HR SSP has embedded or codified knowledge as guidelines for possible actions).

Despite the recognition that the three sub-dimensions of intellectual capital jointly affect value, only a few studies into intellectual capital have actually considered the coexistence of human, social and organisational capitals (Youndt et al, 2004). Those that did have found that, depending on the circumstances, value follows from various interrelations among human, social and organisational capitals. These findings indicate that the interrelations and interactions among the three intellectual capital dimensions are not universally effective in creating value. Reed et al. (2006), for example, studied interactions among human, social and organisational capitals, looking for an effect on performance in banks. They found that human capital and organisational capital interact positively in personal banks but not in commercial banks. Bontis et al. (2001) found that organisational capital mediates the relationship between human capital and performance, but only in service industries. We may therefore conclude that, depending on the context, different combinations of human, 
social and organisational capitals exist that can enhance performance. In shared service provision, organisations have been found to split the delivery of transactional and transformational HR services, rather than bundle both types in a single HR SSP (Ulrich, 1995). We therefore distinguish between transactional and transformational HR SSPs (see Figure 1) and propose that both combine their human, social and organisational capitals differently in order to advance either transactional or transformational HR value. 


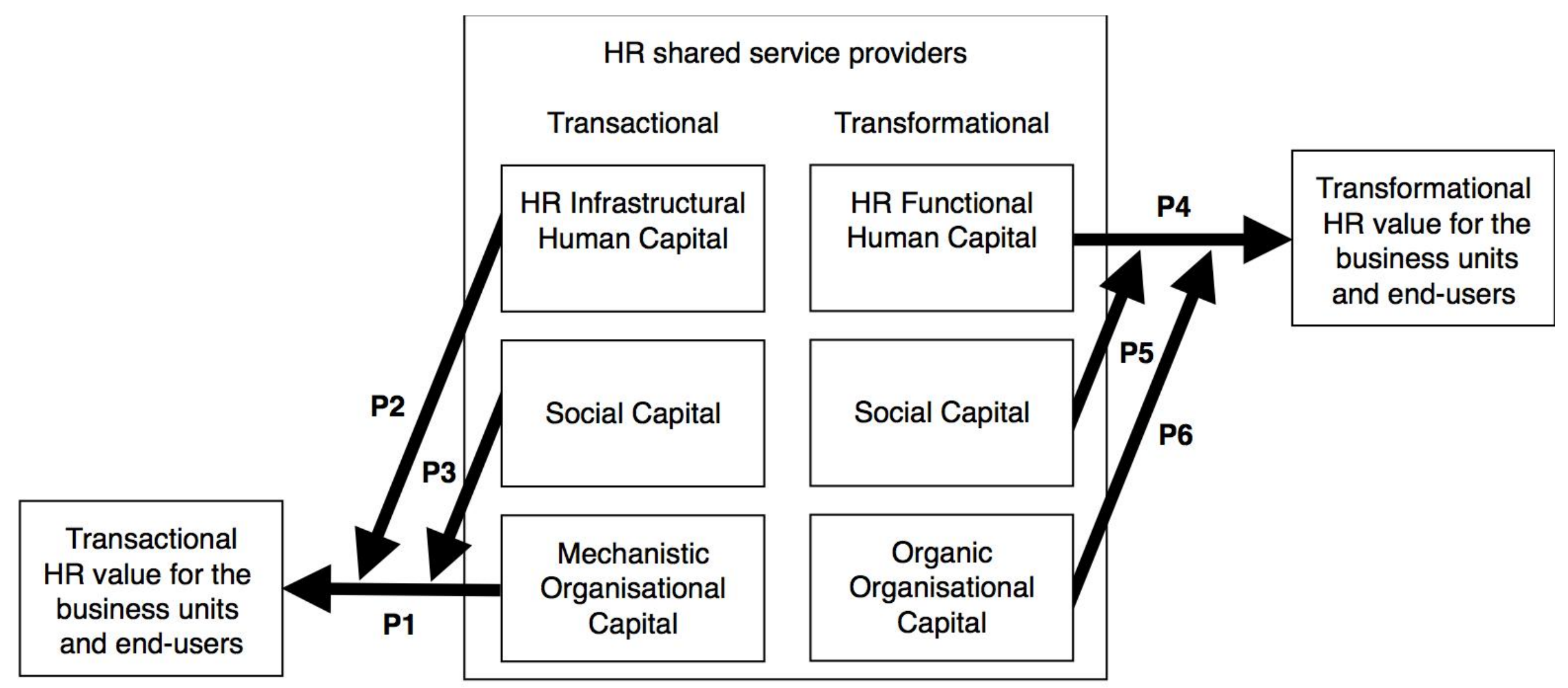

Figure 1. Conceptual framework for HR value creation by HR SSPs 


\subsection{Intellectual capital and transactional HR value creation}

On the basis that clients and end-users value a low-cost, quick, standardised and consistent delivery of transactional HR services, relying on organisational capital may lead to a focus on transactional HR value (Crossan et al., 1999; Haas and Hansen, 2007; Hansen et al., 1999; March and Simon, 1958). Several examples illustrate a link between high levels of knowledge codification and transactional HR value. Knowledge databases, routines and protocols make up an organisation's memory that enables best practices to be re-used, and in so doing reduces the transaction costs associated with, for example, the search for information (Walsh and Ungson, 1991). In securing low-cost service delivery, organisational knowledge from the HR SSP front office may also be used in the back office, preventing employees 'reinventing the wheel'. Haas and Hansen (2007) found that the level of document reworking (i.e. extent to which codified knowledge has to be adapted or modified when being used) was negatively related with the time saved on a task; that is, that end-users are served quicker when HR SSP employees can literally copy documented knowledge, i.e use organisational capital mechanistically. Mechanistic organisation capital in the form of strict rule adherence is valuable in delivering transactional HR services because rule adherence is shown to lead to a consistent service delivery, standardised problem solutions and, ultimately, lower costs (Child, 1973; Hendrickson and Harrison, 1998; Miron et al., 2004; Ostroff and Schmitt, 1993). We therefore argue that mechanistic organisational capital has the potential to lower the costs associated with transactional HR service delivery and meet the administrative needs of end-users and clients:

Proposition 1: The mechanistic organisational capital of HR SSPs is positively and directly related to transactional HR value for clients and end-users. 
Codified knowledge is a static resource that becomes organisational capital, and so supports service delivery, only when put to use by employees (Bontis, 1999). As such, the effect of organisational capital on transactional HR value for clients and end-users is contingent upon the ability of HR SSP employees to utilise it (Cook and Brown, 1999). In other words, HR SSP employees need to have the knowledge, skills and abilities required to put organisational capital to use, which is a function of HR infrastructural human capital. Cooke (2006) found that service employees in a transactional HR SSP received training to increase their skills in tracing and operating the organisational knowledge embedded in online databases and processes. This suggests that employees within a transactional HR SSP possess HR infrastructural human capital and apply this in utilising organisational capital. In other words, employees' skills and knowledge within a transactional HR SSP have a catalytic function in leveraging embedded knowledge. As such, the effect of organisational capital on transactional HR value creation, for clients and end-users, strengthens as employees' HR infrastructural skills and knowledge increase:

Proposition 2: The HR infrastructural human capital within an HR SSP moderates the relationship between mechanistic organisational capital and transactional HR value. The greater the HR infrastructural human capital within an HR SSP, the stronger the relationship between its mechanistic organisational capital and transactional HR value for clients and end-users.

Utilising organisational capital that is mechanistically designed does not necessarily guarantee an efficient and consistent service delivery, and hence transactional HR 
value, because employees may fail to consistently use organisational capital. For instance, organisational processes and routines have been shown to be used differently by employees once they start to rearrange the sequence of actions that together represent processes or routines (Feldman and Pentland, 2003; Pentland and Reuter, 1994). Studies into the usage of information technologies have also revealed that employees may use standard technologies differently and customise their functionalities. These variations occur because employees have different interpretations of the IT functionalities (Bondarouk, 2004; Orlikowski, 2000; Orlikowski and Gash, 1994). Therefore, organisational capital will be used more mechanistically / consistently and hence will affect transactional HR value more strongly when HR SSP employees share a common interpretation of how to use codified knowledge.

To develop a shared interpretation, high levels of social capital are needed (Crossan et al., 1999; Nahapiet and Ghoshal, 1998; Tsai and Ghoshal, 1998). Tsai and Ghoshal (1998) found a positive relationship between the extent of knowledge sharing and shared understanding among employees. As such, through creating a common understanding among HR shared services employees, social capital may ensure that employees have similar and consistent interpretations of how to use infrastructures, which eventually results in a consistent and mechanistic use of organisational capital. Higher levels of social capital can secure a stronger impact of organisational capital on transactional HR value because knowledge exchange results in a more consistent use of codified knowledge among HR SSP employees and, hence, a more consistent delivery of transactional HR services. On this basis, we anticipate that the social capital of an HR SSP will indirectly support transactional HR value creation: 
Proposition 3: The social capital within an HR SSP moderates the relationship between mechanistic organisational capital and transactional HR value. As levels of social capital increase, the relationship between the HR SSP's mechanistic organisational capital and transactional HR value for clients and end-users will strengthen.

\subsection{Intellectual capital and transformational HR value creation}

For two reasons, we expect the creation of transformational HR value for end-users to directly rely on the human capital within an HR SSP. First, to create transformational HR value, transformational HR services will need to be customised. However, service customisation is associated with customer-induced uncertainty for the HR SSP: the uncertainty brought about by interaction with clients and end-users (Tansik, 1990). Clients and end-users participate in the production of services, and may increase uncertainty for the service provider through distorting the service production process or deviating from operating procedures. Given that HR SSPs need to tailor transformational HR services to specific employee groups, they will be subjected to a diversity of end-user and client needs and, hence, high levels of uncertainty (Chowdhury and Miles, 2006; Skaggs and Youndt, 2004). To cope with high-level uncertainty, employees require an elaborate skills set. For example, they should have sufficient human capital to identify varying end-user needs, decide on the appropriate services and determine how to tailor them to specific needs (Tansik, 1990). Highlevel human capital is therefore valuable in delivering transformational HR services. This is consistent with the findings of Skaggs and Youndt (2004), who found that organisations that matched high-level human capital with customised service provision exhibited high levels of performance, whereas companies that used low- 
level human capital to offer customised services experienced poor performance. As such, higher levels of human capital in an HR SSP seem to result in higher levels of transformational HR value.

Second, human capital is considered as tacit, or at least having its roots in tacit knowledge (Polanyi, 1966). As tacit knowledge is difficult to articulate, transfer and imitate (Simonin, 1999; Spender, 1996), the human capital of an HR SSP becomes a valuable and inimitable resource in implementing HR strategies and so supports transformational HR value creation. This is consistent with findings from research that has adopted the knowledge-based view which shows that higher levels of human capital result in higher levels of firm performance and a sustained competitive advantage because firms are better able to implement their strategies than their competitors (Hatch and Dyer, 2004; Hitt et al., 2001; Huselid et al., 1997). Relying on human capital may facilitate a transformational HR SSP to implement an HR strategy better than its competitors and so strengthen the rarity and inimitability of the human capital in the business units; that is, transformational HR value for the business units. More specifically, to develop the human capital in the business units requires knowledge of HR practices and the ability among HR SSP staff to implement these HR practices: that is, HR functional human capital (Han et al., 2006; Huselid et al., 1997). As Huselid et al. (1997) found, the professional HRM capabilities of HR professionals are positively related with strategic HRM effectiveness, such that higher levels of expertise and skills in HRM functional areas (e.g. training or staffing) result in clients and end-users perceiving a better development of talent / human capital within the business units. We propose therefore that the functional HR human capital of HR SSPs has a direct and positive effect on transformational HR value: 
Proposition 4: The HR functional human capital of HR SSPS is positively and directly related to transformational HR value for clients and end-users.

The human capital possessed by any individual employee may generate greater value when combined with the knowledge of others. Employees can integrate knowledge and experiences to strengthen the innovative capability of firms (Subramaniam and Youndt, 2005), to improve organisational processes (Newell et al., 2004) or to create new knowledge (Nahapiet and Ghoshal, 1998). Integrating human capital is valuable in delivering transformational HR services for two reasons. First, in order to deliver customised transformational HR services, service employees need to exchange and integrate their knowledge as it is unlikely that an individual employee will have the ability to cope with all the customer-induced uncertainties (Bowen and Ford, 2002; Hansen et al., 1999). Second, hard-to-imitate human capital strengthens the unique ability of transformational HR SSPs to implement an HR strategy when employees exchange and integrate their knowledge to form hard-to-imitate human capital combinations (Boxall, 1996; Reed et al., 2006).

As the exchange and combination of knowledge is a function of social capital (Nahapiet and Ghoshal, 1998; Tsai and Ghoshal, 1998), the latter strengthens the relationship between human capital and value creation. As evidence, Reed et al. (2006) have shown that the impact of human capital on firm performance is stronger when there is a high level of social capital. Given that social capital probably enhances the impact of human capital on transformational HR value, we propose the following: 
Proposition 5: The social capital within HR SSPS moderates the relationship between HR functional human capital and transformational HR value. As the level of social capital within an HR SSP increases, the relationship between the HR functional human capital of the HR SSP and the transformational HR value for clients and endusers will strengthen.

Although organisational capital has been shown to be valuable in delivering standardised services (Hansen et al., 1999), we argue that codified knowledge can also facilitate the delivery of customised transformational HR services, especially when designed and used organically (Feldman, 2000; Feldman and Pentland, 2003; Pentland and Reuter, 1994). With high levels of customisation, transformational HR SSPs experience high levels of variability in end-user and client needs (Skaggs and Youndt, 2004). In such a situation, flexibility in HR service provision is required to effectively respond to the diverse needs of clients and end-users, and so service providers cannot use codified knowledge as strictly embedded in rules and procedures (Bowen and Ford, 2002; Hansen et al., 1999; Hendrickson and Harrison, 1998). We therefore argue that mechanistic organisational capital reduces transformational HR value.

Rather, organic organisational capital is more valuable in transformational HR service delivery. The study by Pentland and Reuter (1994), conducted within a software support call-centre, showed that service representatives use routines as a 'grammar' for handling customised inquiries, and rearrange the activities that underlie the routine (e.g. opening a call, working on the call, transferring the call back to the user, transferring the call to the back-office or deferring a call). Routines offer flexibility, and opportunities for change, as employees differentiate how the elements 
are enacted. Embedded knowledge may be seen as organic organisational capital in the form of guidelines or sets of possible routines and patterns of action (Feldman, 2000; Pentland and Reuter, 1994) that still provide sufficient autonomy for employees to offer services in a customised way and cope with the diversity of end-user needs. As such, organic organisational capital provides HR SSPs with sufficient flexibility to customise transformational HR services and so create transformational HR value.

More specifically, organisational capital may be seen as providing the opportunity to service employees to improve and utilise their human capital (Appelbaum et al., 2000; Blumberg and Pringle, 1982). Whereas employees use databases and protocols for learning and to strengthen their individual knowledge (Ruta, 2009), routines have been shown to guide service employees as to which assets, such as human capital, they should rely on (Feldman and Pentland, 2003; Pentland and Reuter, 1994). Employing standard operating procedures may lead to more time being available for leveraging human capital as they reduce the time spent searching for solutions (Gilson et al., 2005). Given its supporting function, organisational capital, when used organically, may support HR SSP employees in better leveraging their human capital such that the human capital of the HR SSP has a stronger impact on transformational HR value when organisational capital increases. We therefore propose the following:

Proposition 6: The organic organisational capital within HR SSPS moderates the relationship between $H R$ functional human capital and transformational HR value. The greater the organic organisational capital within an HR SSP, the stronger the relationship between its $H R$ functional human capital and the transformational HR value for clients and end-users. 


\section{Discussion}

The paper set out with the aims of modelling the mechanisms of HR SSP performance and the benefits of HR shared services; and of constructing a measure for the performance of HR SSPs. We first proposed measuring the performance of HR SSPs in terms of HR value (the ratio between use value and exchange value) for clients and end-users. The notion that HR SSPs can create both transactional and transformational HR value led to the development of two sets of propositions. The starting point for developing these propositions was the idea that the knowledge resources of an HR SSP are interdependent, and that it is their combination that creates value for the end-users and clients. First, where an HR SSP offers transactional HR services, we would expect HR value to come directly from the mechanistic organisational capital. The relationship between mechanistic organisational capital and transactional HR value for clients and end-users will strengthen when social capital and HR infrastructural human capital increase. In contrast, transformational HR SSPs primarily rely on their HR functional human capital to create transformational HR value. The contribution of this human capital to transformational HR value will be enhanced if it is combined with high levels of social and organic organisational capitals.

The paper contributes to the existing knowledge in several ways. First, it builds on the emerging studies into HR shared services by articulating the benefits and performance of HR shared services in terms of ensuring HR value, which provides future studies with a measure for assessing the performance of HR SSPs and the effects of implementing HR shared services. Second, while lacking an associated theory on HR shared services (Farndale et al., 2009; Strikwerda, 2004), this paper does propose a theoretical framework for value creation by HR SSPs. This paves the 
way for large-scale research into HR shared services and as such will hopefully encourage researchers to empirically test the relationships between intellectual capital and HR value created by HR SSPs. Our arguments can be extended in future research through studying the impact of HR value on firm performance and strategic success. For instance, in creating use value, HR SSPs ensure that employees' needs are fulfilled. Adopting a social exchange perspective, empirical studies have shown that satisfying employee needs positively affects employee attitudes such as organisational commitment and perceived organisational support, which in turn impact on firm performance (Steers, 1977; Tannenbaum et al., 1991). Therefore, high levels of both transactional and transformational HR value, created by HR SSPs, are likely to result in higher levels of strategic success.

Third, the paper enriches the concept of intellectual capital by offering a contribution to the discussion on intellectual capital configurations started by Youndt et al. (2004). Rather than focusing on whether the human, organisational and social capital levels are high or low within certain intellectual capital configurations (as in Youndt et al., 2004), this paper takes a further step by suggesting that researching the internal dynamics within configurations would clarify how intellectual capital configurations work in practice.

Fourth, this paper extends the discussion on integrating knowledge management and intellectual capital. Traditionally, one stream has focused on explaining differences in performance due to human, organisational and social capitals (Yang and Lin, 2009; Youndt and Snell, 2004), while the other on how human, organisational and social capitals are related (Cabrita and Bontis, 2008; Hansen et al., 1999). Integrating the two streams helps to envisage how intellectual capital creates value, rather than only explaining the differences in levels of value creation. 
From a practical perspective, the paper provides guidelines for HR shared service managers on how to effectively manage HR SSPs. Our arguments suggest that organisations should be aware that the effect of intellectual capital, as bundled in HR SSPs, on HR value depends on the types of service being offered. The ways in which human, social and organisational capitals are to be designed, developed and used should vary as a function of the strategic choice of HR SSPs: whether they deliver transactional or transformational HR services. With transactional HR services, knowledge should be embedded in organisational knowledge and used mechanistically, with investments in HR infrastructural human capital and high levels of social capital supporting the leverage of this organisational capital. Offering transformational HR services, an HR SSP should ensure that its employees have high levels of HR functional human capital, complemented with high levels of social capital and organic organisational capital to guide them towards possible actions to facilitate the utilisation and integration of this human capital. If managers do not fit their use of intellectual capital to the type of HR services being provided by the HR SSP they may risk ending up with low levels of HR value. For example, requiring HR SSP employees to use organisational capital mechanistically may endanger the delivery of high quality customised transformational HR services since this requires more flexible or organic use of organisational capital. Our conceptual framework suggests that HR SSP managers should match the way knowledge resources are designed and used to the service portfolio being offered by their HR SSP.

Although this paper has its limitations, we prefer to see these more as motivations for future research efforts in the field of HR shared services. Although we have conceptualised the concentrated resources of HR SSPs in terms of intellectual capital, which is further operationalised as human, social and organisational capitals, we have 
not considered these elements in depth. Further, the literature provides few insights into how these intellectual capital elements might look. For instance, HR shared services may require HR staff to acquire a new skills set (Redman et al., 2007) and, if so, the existing research into HR competencies to which we referred may provide only limited information on how the human capital within HR SSPs might look. We would encourage further explorative research to improve our understanding of which specific knowledge resources are bundled in HR SSPs, and to consider how different elements of human, social and organisational capitals may affect HR value.

Further, while we have discussed how the consolidated knowledge resources of an HR SSP may affect HR value levels, we ignored the second structural component of HR shared services: delegating control to business units. One should not infer from this that control by business units has no role in HR value creation. Studies into the governance of SSPs have suggested that organisations may differ in the positioning of the HR SSP and, hence, the extent to which control is decentralised (Maatman et al., 2010; Strikwerda, 2004). For instance, an SSP can be positioned as a 'central staff function' that grants only limited decentralised control down to an 'internal joint venture' that then fully decentralises the control over the SSP to the business units (Strikwerda, 2004). While organisational controls ensure that an agent fulfils the desires of the principal, higher levels of control by the business units and end-users are more likely to result in high levels of HR value being created by the HR SSP. More specifically, we envisage that the level of control by the business units will impact on HR value through the intellectual capital of the HR SSPs. In the literature, controls are defined as mechanisms that direct the actions of agents (Jaworski and MacInnis, 1989). From an intellectual capital perspective, one of these activities is the utilisation of knowledge resources by the HR SSP and its staff. In this way, control by 
the business units may ensure that the human, social and organisational capitals of an HR SSP are combined and used in a manner that supports meeting client and end-user needs. In other words, the level of business unit control is probably an antecedent of the value-creating intellectual capital of an HR SSP. We would encourage future research to test whether business unit control is related to HR value and, if so, whether the intellectual capital of an HR SSP mediates this relationship.

\section{Conclusions}

The conceptual framework presented in this paper provides insights into how the intellectual capital within an HR SSP drives value creation. Human, social and organisational capitals are viewed both as interdependent and as drivers of HR value, which represents the performance of HR SSPs in a ratio of use value to exchange value. In particular, our paper considers how these intellectual capital sub-dimensions reinforce each other and, as such, together boost the HR value created by both transactional and transformational HR SSPs. Transactional HR value creation will primarily rely on interactions between mechanistic organisational capital, HR infrastructural human capital and social capital. Transformational HR value we assume, will follow from the interrelations among HR functional human capital, social capital and organic organisational capital. While further conceptual and empirical work is needed to better understand value creation by HR shared services, a focus on the interrelationships among the categories of intellectual capital would facilitate an analysis of how the centralised knowledge resources of HR SSPs affect HR value, and how HR SSPs may use their human, social and organisational capitals to create HR value. 


\section{References}

Alleyne, C. Kakabadse, A. and Kakabadse, N. K. (2007), "Using the intranet: an exploratory analysis of its impact on managerial satisfaction with the HR function", Personnel Review, Vol. 36, No. 2, pp. 295-310.

Appelbaum, E. Bailey, T. Berg, P. and Kalleberg, A. (2000), Manufacturing Advantage: Why High-Performance Work Systems Pay Off, Cornell University Press, Ithaca.

Barney, J. B. (1986), "Organizational culture: can it be a source of sustained competitive advantage?", Academy of Management Review, Vol. 11, No. 3, pp. 656-665.

Barney, J. B. (2001), "Is the resource-based 'view' a useful perspective for strategic management research? Yes", Academy of Management Review, Vol. 26, No. 1, pp. 41-56.

Becker, B. E. and Huselid, M. A. (2006), "Strategic human resource management: where do we go from here?", Journal of Management, Vol. 32, No. 6, pp. 898925.

Blumberg, M. and Pringle, C. D. (1982), "The missing opportunity in organizational research: some implications for a theory of work performance", Academy of Management Review, Vol. 7, No. 4, pp. 560-569.

Bondarouk, T. V. (2004), Using Group Learning to Enhance the Implementation of Information Technology: The Results of Discource Analysis. Unpublished Doctoral Thesis, University of Twente, Enschede, The Netherlands.

Bondarouk, T. V. Maatman, M. and Meijerink, J. G. (2010), Human Resource Shared Services: Business Models and Value Creation, Unpublished Manuscript, University of Twente, The Netherlands.

Bontis, N. (1998), "Intellectual capital: an exploratory study that develops, measures and models", Management Decision, Vol. 36, No. 2, pp. 63-76.

Bontis, N. (1999), "Managing organizational knowledge by diagnosing intellectual capital: framing and advancing the state of the field", International Journal of Technology Management, Vol. 18, No. 5-8, pp. 433-463.

Boselie, P. and Paauwe, J. (2005), "Human resource function competencies in European companies", Personnel Review, Vol. 34, No. 5, pp. 550-566.

Bowen, J. and Ford, R. C. (2002), "Managing service organizations: does having a 'thing' make a difference?", Journal of Management, Vol. 28, No. 3, pp. 447469.

Bowman, C. and Ambrosini, V. (2000), "Value creation versus value capture: towards a coherent definition of value in strategy", British Journal of Management, Vol. 11, No. 1, pp. 1-15.

Boxall, P. (1996), "The strategic HRM debate and the resource-based view of the firm", Human Resource Management Journal, Vol. 6, No. 3, pp. 59-75.

Bukh, P. N. Larsen, H. T. and Mouritsen, J. (2001), "Constructing intellectual capital statements", Scandanavian Journal of Management, Vol. 17, No. 1, pp. 87108.

Buyens, D. and De Vos, A. (2001), "Perceptions of the value of the HR function", Human Resource Management Journal, Vol. 11, No. 3, pp. 70-89.

Cabrita, M. and Bontis, N. (2008), "Intellectual capital and business performance in the Portuguese banking industry", International Journal of Technology Management, Vol. 43, No. 1, pp. 212-237. 
Child, J. (1973), "Predicting and understanding organizational structure", Administrative Science Quarterly, Vol. 18, No. 2, pp. 168-185.

Chowdhury, S. and Miles, G. (2006), "Customer-induced uncertainty in predicting organizational design: empirical evidence challenging the service versus manufacturing dichotomy", Journal of Business Research, Vol. 59, No. 1, pp. 121-129.

Coleman, J. S. (1988), "Social capital in the creation of human capital", American Journal of Sociology, Vol. 94, No. Supplement, pp. S95-S120.

Cook, S. D. N. and Brown, J. S. (1999), "Bridging epistemologies: the generative dance between organizational knowledge and organizational knowing", Organization Science, Vol. 10, No. 4, pp. 381-400.

Cooke, F. L. (2006), "Modeling an HR shared service center: experience of an MNC in the United Kingdom", Human Resource Management, Vol. 45, No. 2, pp. 211-227.

Cronin, J. J. Brady, M. K. and Hult, G. T. (2000), "Assessing the effects of quality, value and customer satisfaction on consumer behavioral intentions in service environments", Journal of Retailing, Vol. 76, No. 2, pp. 193-218.

Crossan, M. M. Lane, H. W. and White, R. E. (1999), "An organizational learning framework: from intuition to institution", Academy of Management Review, Vol. 24, No. 3, pp. 522-537.

Daft, R. L. and Weick, K. E. (1984), "Toward a model of organizations as interpretation systems", Academy of Management Review, Vol. 9, No. 2, pp. 284-295.

Eisenhardt, K. M. and Sull, D. N. (2001), "Strategy as simple rules", Harvard Business Review, Vol. 79, No. pp. 106-116.

Farndale, E. and Paauwe, J. (2008), "Restructuring the HR function: HR shared service centers in the Netherlands", in G. Martin, M. Reddington and H. Alexander (Ed.), Technology, Outsourcing, and Transforming HR (pp. 105135), pp. 105-135.

Farndale, E. Paauwe, J. and Hoeksema, L. (2009), "In-sourcing HR: shared service centers in the Netherlands", International Journal of Human Resource Management, Vol. 20, No. 3, pp. 544-561.

Feldman, M. S. (2000), "Organizational routines as a source of continuous change", Organization Science, Vol. 11, No. 6, pp. 611-629.

Feldman, M. S. and Pentland, B. T. (2003), "Reconceptualizing organizational routines as a source of flexibility and change", Administrative Science Quarterly, Vol. 48, No. 1, pp. 94-118.

Gibb, S. (2001), "The state of human resource management: evidence from employees' views of HRM systems and staff", Employee Relations, Vol. 23, No. 4, pp. 318-336.

Gilson, L. L. Mathieu, J. E. Shalley, C. E. and Ruddy, T. M. (2005), "Creativity and standardization: complementary or conflicting drivers of team effectiveness?", Academy of Management Journal, Vol. 48, No. 3, pp. 521-531.

Grant, R. M. (1996), "Toward a knowledge-based theory of the firm", Strategic Management Journal, Vol. 17, No. Winter Special Issue, pp. 109-122.

Grewal, D. Monroe, K. B. and Krishan, R. (1998), "The effects of price-comparison advertising on buyers' perceptions of acquisition value, transaction value, and behavioral intentions", Journal of Marketing, Vol. 62, No. 2, pp. 46-59. 
Haas, M. R. and Hansen, M. T. (2007), "Different knowledge, different benefits: towards a productivity perspective on knowledge sharing in organizations", Strategic Management Journal, Vol. 28, No. 11, pp. 1133-1153.

Han, J. Chou, P. Chao, M. and Wright, P. M. (2006), "The HR competencies-HR effectiveness link: a study in Taiwanese high-tech companies", Human Resource Management, Vol. 45, No. 3, pp. 391-406.

Hansen, M. T. Nohria, N. and Tierney, T. (1999), "What's your strategy for managing knowledge?", Harvard Business Review, Vol. 77, No. 2, pp. 106-116.

Hatch, N. W. and Dyer, J. H. (2004), "Human capital and learning as a source of sustained sompetitive advantage", Strategic Management Journal, Vol. 25, No. 12, pp. 1155-1178.

Hendrickson, C. L. and Harrison, W. (1998), "Consistency vs flexibility: the impact of employee voice in rule-based and descretionary decision procedures", Employee Responsibilities and Rights Journal, Vol. 11, No. 4, pp. 279-295.

Hitt, M. A. Bierman, L. Shimizu, K. and Kochhar, R. (2001), "Direct and moderating effects of human capital on strategy and performance in professional service firms: a resource-based perspective", Academy of Management Journal, Vol. 44, No. 1, pp. 13-28.

Huselid, M. A. Jackson, S. E. and Schuler, R. S. (1997), "Technical and strategic human resource management effectiveness as determinants of firm performance", Academy of Management Journal, Vol. 40, No. 1, pp. 171-188.

Janssen, M. and Joha, A. (2006), "Motives for establishing shared service centers in public administrations", International Journal of Information Management, Vol. 26, No. 2, pp. 102-115.

Jaworski, B. J. and MacInnis, D. J. (1989), "Marketing jobs and management Controls: toward a framework", Journal of Marketing Research, Vol. 26, No. 4, pp. 406-419.

Lapierre, J. Filiatrault, P. and Chebat, J. (1999), "Value strategy rather than quality strategy: a case of business-to-business professional services", Journal of Business Research, Vol. 45, No. 2, pp. 235-246.

Lepak, D. P. Bartol, K. M. and Erhardt, N. L. (2005), "A contingency framework for the delivery of HR practices", Human Resource Management Review, Vol. 15, No. 2, pp. 139-159.

Lepak, D. P. Liao, H. Chung, Y. and Harden, E. E. (2006), "A conceptual review of human resource management systems in strategic human resource management research", in J. Martocchio (Ed.), Research in Personnel and Human Resource Management: A Research Annual (pp. 217-271), JAI Press, Greenwich, CT, pp. 217-271.

Lepak, D. P. and Snell, S. A. (2002), "Examining the human resource architecture: the relationships among human capital, employment and human resource configurations", Journal of Management, Vol. 28, No. 4, pp. 517-543.

Liao, H. Toya, K. Lepak, D. P. and Hong, Y. (2009), "Do they see eye to eye? Management and employee perspective of high-performance work systems and influence processes on service quality", Journal of Applied Psychology, Vol. 94, No. 2, pp. 371-391.

Maatman, M. Bondarouk, T. V. and Looise, J. C. (2010), "Conceptualising the capabilities and value creation of HRM shared services models", Human Resource Management Review, Vol. 20, No. 4, pp. 327-339.

March, J. G. and Simon, H. A. (1958), Organizations, Wiley, New York. 
Miron, E. Erez, M. and Naveh, E. (2004), "Do personal characteristics and cultural values that promote innovation, quality and efficiency compete or complement each other?", Journal of Organizational Behaviour, Vol. 25, No. 2, pp. 175199.

Mitsuhashi, H. Park, H. J. Wright, P. M. and Chua, R. S. (2000), "Line and HR executives' perceptions of HR effectiveness in firms in the People's Republic of China", International Journal of Human Resource Management, Vol. 11, No. 2, pp. 197-216.

Nahapiet, J. and Ghoshal, S. (1998), "Social capital, intellectual capital and the organizational advantage", Academy of Management Review, Vol. 23, No. 2, pp. 242-266.

Newell, S. Tansley, C. and Huang, J. (2004), "Social capital and knowledge integration in an ERP project team: the importance of bridging and bonding", British Journal of Management, Vol. 15, No. S1, pp. S43-S57.

Orlikowski, W. J. (2000), "Using technology and constituting structures: a practice lens for studying technology in organizations", Organization Science, Vol. 11, No. 4, pp. 404-428.

Orlikowski, W. J. and Gash, D. C. (1994), "Technological frames: making sense of information technology in organizations", ACM Transactions on Information Systems, Vol. 12, No. 2, pp. 174-207.

Ostroff, C. and Schmitt, N. (1993), "Configurations of organizational effectiveness and efficiency", Academy of Management Journal, Vol. 36, No. 6, pp. 13451361.

Paauwe, J. (2004), HRM and performance: unique approaches for achieving longterm viability, Oxford University Press, Oxford.

Penrose, E. T. (1952), "Biological analogies in the theory of the firm", American Economic Review, Vol. 42, No. 5, pp. 804-819.

Pentland, B. T. and Reuter, H. H. (1994), "Organizational routines as grammars of action", Administrative Science Quarterly, Vol. 39, No. 3, pp. 484-510.

Polanyi, M. (1966), The Tacit Dimension, Routledge and Kegan Paul, London.

Priem, R. L. (2007), "A consumer perspective on value creation", Academy of Management Review, Vol. 32, No. 1, pp. 219-235.

Quinn, B. E. Cooke, R. S. and Kris, A. (2000), Shared Services: Mining for Corporate Gold, Financial Times, Harlow.

Redman, R. Snape, E. Wass, J. and Hamilton, P. (2007), "Evaluating the human resource shared services model: evidence from the NHS", International Journal of Human Resource Management, Vol. 18, No. 8, pp. 1486-1506.

Reed, K. K. Lubatkin, M. and Srinivasan, N. (2006), "Proposing and testing an intellectual capital-based view of the firm", Journal of Management Studies, Vol. 43, No. 4, pp. 867-893.

Reilly, P. (2000), HR Shared Services and the Realignment of HR (Vol. 368), Institute for Employment Studies, Brighton.

Ruta, C. D. (2009), "HR portal alignment for the creation and development of intellectual capital", International Journal of Human Resource Management, Vol. 20, No. 3, pp. 562-577.

Simonin, B. L. (1999), "Ambiguity and the process of knowledge transfer in strategic alliances", Strategic Management Journal, Vol. 20, No. 7, pp. 595-623.

Skaggs, B. C. and Youndt, M. A. (2004), "Strategic positioning, human capital, and performance in service organizations: a customer interaction approach", Strategic Management Journal, Vol. 25, No. 1, pp. 85-99. 
Snell, S. A. and Dean, J. W. (1992), "Integrated manufacturing and human resource management: a human capital perspective", Academy of Management Journal, Vol. 35, No. 3, pp. 467-504.

Spender, J. C. (1996), "Making knowledge the basis of a dynamic theory of the firm", Strategic Management Journal, Vol. 17, No. Winter Special Issue, pp. 45-62.

Steers, R. M. (1977), "Antecedents and outcomes of organizational commitment", Administrative Science Quarterly, Vol. 22, No. 1, pp. 46-56.

Strikwerda, J. (2004), Shared service centers: van kostenbesparing naar waardecreatie, Koninklijke Van Gorcum BV., Assen.

Subramaniam, M. and Youndt, M. A. (2005), "The influence of intellectual capital on the types of innovation capabilities", Academy of Management Journal, Vol. 48, No. 3, pp. 450-463.

Tannenbaum, S. I. Mathieu, J. E. Salas, E. and Cannon-Bowers, J. A. (1991), "Meeting trainees' expectations: the influence of training fulfillment on the development of commitment, self-efficacy, and motivation", Journal of Applied Psychology, Vol. 76, No. 6, pp. 759-769.

Tansik, D. A. (1990), "Balance in service systems design", Journal of Business Research, Vol. 20, No. 1, pp. 55-61.

Tsai, W. and Ghoshal, S. (1998), "Social capital and value creation: the role of intrafirm networks", Academy of Management Journal, Vol. 41, No. 4, pp. 464-476.

Tsui, A. S. (1987), "Defining the activities and effectiveness of the human resource department: a multiple constituency approach", Human Resource Management, Vol. 26, No. 1, pp. 35-69.

Ulrich, D. (1995), "Shared services: from vogue to value", Human Resource Planning, Vol. 18, No. 3, pp. 12-23.

Ulrich, D. Brockbank, W. Johnson, D. Sandholtz, K. and Younger, J. (2008), HR Competencies: Mastery at the Intersection of People and Business, Society for Human Resource Management, Alexandria.

Walsh, J. P. and Ungson, G. R. (1991), "Organizational memory", Academy of Management Review, Vol. 16, No. 1, pp. 57-91.

Yang, C. and Lin, Y. (2009), "Does intellectual capital mediate the relationship between HRM and organizational performance? Perspective of a healthcare industry in Taiwan", International Journal of Human Resource Management, Vol. 20, No. 9, pp. 1965-1984.

Yeung, A. Woolcock, P. and Sullivan, J. (1996), "Identifying and developing HR competencies for the future", Human Resource Planning, Vol. 19, No. 4, pp. 48-58.

Youndt, M. A. and Snell, S. A. (2004), "Human resource configurations, intellectual capital and organizational performance", Journal of Managerial Issues, Vol. 16, No. 3, pp. 337-360.

Youndt, M. A. Subramaniam, M. and Snell, S. A. (2004), "Intellectual capital profiles: an examination of investments and returns", Journal of Management Studies, Vol. 41, No. 2, pp. 335-361.

Zeithaml, C. P. (1988), "Consumer perceptions of price, quality, and value: a meansend model and synthesis of evidence", Journal of Marketing, Vol. 52, No. 3, pp. 2-22. 